\title{
1 Initiation and long-term instability of the East Antarctic Ice Sheet
}

3 Sean P. S. Gulick ${ }^{1}$, Amelia E. Shevenell ${ }^{2 *}$, Aleksandr Montelli ${ }^{1 \dagger}$, Rodrigo Fernandez ${ }^{1}$,

4 Catherine Smith $^{2}$, Sophie Warny ${ }^{3}$, Steven M. Bohaty ${ }^{4}$, Charlotte Sjunneskog ${ }^{5}$, Amy

5 Leventer $^{6}$, Bruce Frederick ${ }^{1 \dagger \dagger}$, Donald D. Blankenship ${ }^{1}$

6

$7{ }^{1}$ Institute for Geophysics, Jackson School of Geosciences, University of Texas at Austin, Austin,

8 Texas 78758, USA.

9

$10{ }^{2}$ College of Marine Science, University of South Florida, Saint Petersburg, Florida, 33701, USA.

11

$12{ }^{3}$ Department of Geology and Geophysics and Museum of Natural Science, Louisiana State

13 University, Baton Rouge, Louisiana, 70803, USA.

14

$15{ }^{4}$ School of Ocean and Earth Science, University of Southampton, Southampton S0143ZH, UK.

16

$17{ }^{5}$ Antarctic Marine Geological Research Facility, Florida State University, Tallahassee, Florida, 1832306, USA.

19

$20{ }^{6}$ Geology Department, Colgate University, Hamilton, New York, 13346, USA.

21

22

*Joint first-author.

$\dagger$ Present Address: Scott Polar Research Institute, University of Cambridge, Cambridge, CB2 1ER, UK. $\dagger \dagger$ Present Address: Department of Geology, University of Kansas, Lawrence, Kansas, 66045, USA. 
23 Continental-scale Antarctic ice sheets have evolved over the last 50 million years ${ }^{1-4}$. 24 However, sparse ice-proximal records ${ }^{5-8}$ limit understanding of past East Antarctic 25 Ice Sheet (EAIS) behavior and thus, our ability to evaluate its response to ongoing 26 environmental change. The EAIS is marine-based within the Aurora Subglacial Basin 27 (ASB), indicating that this catchment, which drains ice to the Sabrina Coast, may be sensitive to climate perturbations ${ }^{9-11}$. Here we show, using marine geological and geophysical data from the continental shelf seaward of the ASB, that marineterminating glaciers existed at the Sabrina Coast by the early-to-middle Eocene. This finding implies substantial ice volume in the ASB before continental-scale marineterminating ice sheets were established $\sim 34$ million years ago ${ }^{1-4}$. Subsequently, ice advanced and retreated from the ASB and across the continental shelf at least eleven times during the Oligocene and Miocene. Tunnel valleys ${ }^{12}$ associated with half of these glaciations indicate a surface meltwater-rich sub-polar glacial system existed under climate conditions similar to those anticipated with continued anthropogenic warming $^{10,11}$. Cooling since the Late Miocene ${ }^{13}$ resulted in an expanded polar EAIS and a limited ASB catchment response to Pliocene warmth ${ }^{14-16}$. Geologic records indicate that atmospheric temperature and surface-derived meltwater may play important roles in Antarctic ice mass balance under warmer than present climates, The East Antarctic Ice Sheet (EAIS) response to anthropogenic warming and contribution to global sea level are the largest uncertainties in climate models because EAIS

45 formation, evolution, and behavior during past warm climates are poorly understood ${ }^{10,11}$.

46 Deep-sea benthic foraminifer oxygen isotopes $\left(\delta^{18} \mathrm{O}\right)$ indicate that during the early

47 Eocene (53-51 million years ago (Ma)), Earth experienced the warmest conditions of the

48 past 65 million years (myr) ${ }^{1,4,17,18}$. This warmth was followed by $\sim 15$ myr of cooling,

49 declining atmospheric $\mathrm{CO}_{2}$, tectonic reorganizations, and development of continental-

50 scale Antarctic ice sheets by the earliest Oligocene $(33.6 \mathrm{Ma})^{1-4,17-19}$. As atmospheric $\mathrm{CO}_{2}$ 
51 declined through the Oligocene and Miocene, deep-sea $\delta^{18} \mathrm{O}$ and far-field sea level

52 records suggest that ice sheets advanced to and retreated from Antarctica's continental

53 shelves in response to astronomically-paced changes in solar insolation ${ }^{3,4,18,20,21}$. These

54 records also suggest larger Antarctic ice sheets with less pronounced growth and decay

55 cycles after the middle Miocene $(\sim 13.8 \mathrm{Ma})^{1,4}$, when global climate was cool and

56 atmospheric $\mathrm{CO}_{2}$ concentrations low, relative to the Eocene and Oligocene ${ }^{4,17}$. While far-

57 field records provide a general framework for understanding Cenozoic Antarctic

58 cryosphere development, these records provide little direct evidence for ice location,

59 extent, or thermal conditions required to assess climate forcings and feedbacks involved

60 in Antarctic cryosphere and global climate evolution and are complicated by Northern

61 Hemisphere ice volume in the Plio-Pleistocene ${ }^{1,3,4}$.

62

63 East Antarctic continental margin and the Southern Ocean sediments provide direct

64 evidence of EAIS evolution, indicating regional marine-terminating ice in the late

65 Eocene $^{22-24}$ and astronomically-paced glacial-interglacial cycles through the Pliocene $e^{5,6,14}$.

66 However, existing ice-proximal records are geographically limited and temporally

67 discontinuous, making regional comparisons difficult. Recent ice sheet models provide

68 additional insight into EAIS evolution ${ }^{10,11,25}$. Outputs indicate that EAIS catchments with

69 deep landward-dipping subglacial topography and surface meltwater, including the

70 Aurora Subglacial Basin (ASB), may be sensitive to climate perturbations (e.g.

71 atmospheric and/or oceanic temperatures, atmospheric $\mathrm{CO}_{2}$, sea level) ${ }^{9-11,25}$. However,

72 outputs depend on poorly constrained initial boundary conditions ${ }^{17,24,25}$, feedbacks ${ }^{18}$, and

73 retreat mechanisms ${ }^{11}$. Thus, significant uncertainties remain regarding EAIS evolution 
74 that can only be resolved with well-dated ice-proximal marine geologic and geophysical 75 data $^{1,19}$.

77 To improve predictions of future EAIS response to warming and contribution to global

78 sea level rise ${ }^{10,11}$, knowledge of EAIS evolution in catchments with large potential sea-

79 level contributions is critical. The low-lying glacially sculpted ASB catchment ( $\sim 3-5 \mathrm{~m}$

80 sea-level equivalent ice ${ }^{9,15,26}$; Fig. 1a) drains ice from the Gamburtsev Mountains to the

81 Sabrina Coast via the Totten Glacier, which is experiencing the largest mass loss in East

82 Antarctica $^{27}$ and is influenced by warm subsurface (deeper than $400 \mathrm{~m}$ ) ocean waters at

83 its grounding line ${ }^{28}$. The ASB catchment consists of several over-deepened basins ${ }^{15,26}$ and

84 hosts an active subglacial hydrological system that drains basal meltwater to the ocean ${ }^{29}$,

85 suggesting that regional outlet glaciers may be susceptible to both progressive retreat ${ }^{13}$

86 and changing subglacial hydrology $y^{29}$. Thus, regional glacial dynamics and, ultimately, sea

87 level contribution during a given warm interval depends on both catchment and glacier

88 boundary conditions (e.g., subglacial topography, substrate, and/or meltwater

89 presence/volume) coupled to atmospheric and oceanic forcings.

91 We present the first ice-proximal marine geophysical and geological records of ASB

92 glacial evolution (Methods; Figs. 1b, 2, 3a). To document regional glacial development,

93 ice dynamics, and the timing of significant environmental transitions, we integrate

94 seismic reflection and sedimentary data from the Sabrina Coast continental shelf, at the

95 outlet of the ASB (Fig. 1b). This margin formed during Late Cretaceous rifting of

96 Antarctica and Australia, with tectonic subsidence continuing through the Paleogene ${ }^{8}$. 
97 The present-day continental shelf is $\sim 200 \mathrm{~km}$ wide, $\sim 600 \mathrm{~m}$ deep, and slopes landward

98 (Fig. 1b). We imaged $\sim 1300 \mathrm{~m}$ of dipping sedimentary strata that overlie acoustic

99 basement on the inner continental shelf (Methods; Fig. 1b). We identified three distinct

100 packages of sedimentary rocks bounded by basement, regionally extensive

101 unconformities, and the seafloor, termed Megasequences I-III (MS-I, -II, -III; Figs. 2a,

102 2c, 3a, Extended Data Fig. 1). Glacial erosion truncated imaged reflectors at the sea floor,

103 allowing us to recover and date strata near the top of MS-I and at the base of MS-III

104 (Methods; Figs. 2a, 2c).

105

106 The deepest unit, MS-I, overlies basement and consists of a $\sim 620 \mathrm{~m}$ thick, seaward

107 dipping sequence of low-amplitude discontinuous reflectors that increase in amplitude

108 and lateral continuity up-section (Methods; Fig. 2a, Extended Data Fig. 1). No evidence

109 of glacial erosion exists within these strata (Figs. 2a, 3a, Extended Data Fig. 1). On the

110 mid-shelf, we imaged two intervals of inclined stratal surfaces (clinoforms), indicating

111 times of high sediment flux to an unglaciated continental margin (Fig. 2a). Piston core

112 NPB14-02 JPC-55 (1.69 m) recovered mica-rich silty sands 15-20 m below the upper

113 clinoform (Methods; Fig. 2a, Extended Data Figs. 1b, 2a, Extended Data Table 1).

114 Terrestrial palynomorphs and benthic foraminifers indicate that these marine sediments

115 are late Paleocene in age (Methods; Fig. 2b, Extended Data Figs. 1, 2, 5, Extended Data

116 Tables 2, 3), confirming the pre-glacial seismic interpretation of MS-I.

117

118 Above the upper clinoform, within MS-I, are a series of moderate- to high-amplitude,

119 laterally variable reflectors (gray shading; Methods; Fig. 2a, Extended Data Fig. 1). 
120 Piston core NBP14-02 JPC-54 (1.2 m; Methods; Fig. 2a, Extended Data Figs. 1b, 3),

121 recovered from this interval, contains centimeter-scale lonestones interpreted as ice-rafted

122 debris (IRD). Terrestrial palynomorphs indicate that these sediments are of early-to-

123 middle Eocene age (Methods; Fig. 2b, Extended Data Table 2). Laterally variable

124 reflectivity without chaotic seismic facies, with IRD, and no evidence for cross-shelf

125 glacial erosion indicate that marine-terminating glaciers were present at the Sabrina Coast

126 by the middle Eocene, but grounded ice had not yet advanced across the shelf (Figs. 2a,

$1273 a)$.

128

129 MS-I strata reveal episodes of enhanced sediment flux from the ASB, followed by the

130 early-to-middle Eocene arrival of marine-terminating glaciers to the Sabrina Coast.

131 Models and observations indicate that Antarctica's ice sheets nucleated in the higher

132 elevations of the Gamburtsev Mountains and first reached the ocean near the Sabrina

133 Coast and Prydz Bay ${ }^{19}$, increasing sediment flux to the Australo-Antarctic Gulf ${ }^{30}$. Within

134 the ASB are a series of topographically constrained basins that likely hosted

135 progressively larger ice volumes ${ }^{15,26}$ as ice expanded in the catchment (Fig. 1a). We

136 speculate that after the early Eocene climate optimum (53-51 Ma), as regional and global

137 temperatures cooled and atmospheric $\mathrm{CO}_{2}$ declined ${ }^{17,18}$ (Figs. 3b-c), glacial ice breached

138 the northern ASB highlands ${ }^{26}$, allowing marine-terminating glaciers to deliver IRD to the

139 Sabrina Coast shelf by the early-to-middle Eocene (Figs. 1a, 2a, Extended Data Fig. 2).

140 This finding is significant and indicates 1) substantial East Antarctic ice volume by the

141 early-to-middle Eocene and 2) the relatively early arrival of marine-terminating glaciers

142 to the Sabrina Coast, compared with late Eocene arrivals in Prydz Bay and the Weddell 
$143 \mathrm{Sea}^{22-24}$. Due to the relative paucity of Eocene data from Antarctica's margins, it is not

144 clear if this early arrival is unique to the Sabrina Coast, or if equivalent data have not yet

145 been recovered.

146

147 Up-section ( $\sim 13 \mathrm{~m})$ from core JPC-54, the deepest regionally mappable roughly-eroded

148 surface (dark blue horizon; Figs. 2a, 3a, Extended Data Fig. 1) separates MS-I from MS-

149 II strata and provides the first preserved evidence of grounded ice on the Sabrina Coast

150 shelf (Methods). MS-II is up to $675 \mathrm{~m}$ thick with ten additional erosive surfaces (gray

151 numbered horizons; Fig. 3a, ED Fig. 1) that truncate reflectors and exhibit rough

152 morphology and/or channels indicative of glacial erosion in a meltwater-rich

153 environment ${ }^{7,12,29,30}$ (Methods). Between erosive surfaces, we observe strata with parallel

154 high-amplitude reflectivity and prograding strata of varying thickness (Methods), which

155 indicate open marine conditions and intervals of high sediment flux ${ }^{7,8}$, respectively,

156 between the 11 glacial advances and retreats from the ASB.

158 Unlike previously imaged East Antarctic shelf sequences ${ }^{7,8}$, Sabrina Coast MS-II reveals

159 multiple erosive surfaces $(2-6,8,9)$ with U-shaped channels carved into sedimentary

160 strata (Fig. 3a). Based upon geometry and size (Methods; $\leq 170 \mathrm{~m}$ deep; $1150 \mathrm{~m}$ wide),

161 these channels are consistent with subglacial tunnel valleys observed in surface

162 meltwater-rich sub-polar glacial systems ${ }^{12}$. The most significant channels are associated

163 with surfaces 3-5, 8, and 9 (Fig. 3a, Extended Data Fig. 1e). Overlying erosive surface 11

164 (Fig. 3a, Extended Data Fig. 1e) is a $330 \mathrm{~m}$ thick sequence of seaward dipping strata

165 devoid of rough erosional surfaces, indicating prolonged continental shelf progradation 
166 and/or high sediment flux in an open marine setting ${ }^{7,8}$. A regional landward-dipping

167 angular unconformity truncates seaward-dipping MS-II (and in some places, MS-I) strata

168 (light blue horizon; Figs. 2a, 2c, 3a, Extended Data Fig. 1). Late Miocene-to-earliest

169 Pliocene diatomites were recovered from and immediately above the unconformity (Figs.

170 2c-d, Extended Data Figs. 1, 4, 6). As we may not have recovered sediments below the

171 unconformity, we consider the late Miocene ( 7-5.5 Ma) the youngest possible age for

172 the MS-III base (Fig. 2d).

173

174 Ice advanced across the Sabrina Coast continental shelf at least 11 times from the early-

175 to-middle Eocene to late Miocene (Fig. 3a), when average atmospheric $\mathrm{CO}_{2}$

176 concentrations (Fig. 3b), global temperatures (Fig. 3c), and global sea levels (Fig. 3d)

177 were similar to or higher than present ${ }^{4,17,18}$. Without additional age constraints, the pacing

178 of these glaciations is unknown, but far-field and ice-proximal records indicate

179 cryosphere sensitivity to astronomically-paced insolation changes during the Oligo-

180 Miocene $e^{5,20,21}$. The scale of Sabrina Coast shelf tunnel valleys and the presence of similar

181 channels within the ASB catchment, $400 \mathrm{~km}$ from the present grounding line, suggest

182 that regional subglacial hydrologic systems were fed by large volumes of surface

183 meltwater during Oligo-Miocene glacial-interglacial cycles (Methods) ${ }^{11,15}$. Thus, during

184 climates similar to or warmer than present, surface-derived meltwater may play an

185 important role in EAIS behavior ${ }^{29}$, as indicated by models ${ }^{11}$. The prograding sequence at

186 the top of MS-II is similar to middle to late Miocene sequences in Wilkes Land and Prydz

187 Bay, which reflect the transition from sub-polar to polar glacial regimes ${ }^{7,8}$ (Fig. 3a,

188 Extended Data Fig. 1e). 
190 Above the regional unconformity, MS-III consists of a $\leq 110$ veneer of sub-horizontal to

191 landward-dipping strata that thicken landward, indicating substantial glacial erosion of

192 MS-II and/or lower regional sediment flux and onset of ice loading by the late Miocene ${ }^{8}$

193 (Methods; Figs. 2a, 2c, 3a, Extended Data Fig. 1). MS-III strata contain no visible

194 channels, suggesting reduced regional surface meltwater influence and/or more diffuse

195 basal meltwater flux ${ }^{12,15,26,29}$. High-amplitude reflectors (Fig. 3a) within acoustically

196 chaotic MS-III strata indicate erosional surfaces in late Miocene to Pleistocene tills

197 (Methods) and advance/retreat of an expanded EAIS ${ }^{15}$. Open marine sediments are

198 present, but the lack of significant accumulation and/or preservation suggests limited

199 regional ice retreat and/or shorter interglacials since the late Miocene (Methods; Figs. 2c,

200 3a, Extended Data Fig. 1).

201

202 An expanded polar EAIS occupied the ASB catchment and Sabrina Coast continental

203 shelf since the late Miocene ${ }^{15}$, coincident with significant global climate ,carbon and

204 hydrologic cycle reorganizations ${ }^{4,13}$, continent-wide ice sheet expansion and

205 stabilization ${ }^{7,8,13}$, Antarctic Circumpolar Current intensification, Southern Ocean cooling,

206 and modern meridional thermal gradient development (Fig. 3b) ${ }^{1,13}$. Atmospheric cooling

207 likely limited the amount of regional surface ablation, resulting in ice expansion and

208 reduced surface-derived meltwater in the ASB catchment. Although open marine

209 conditions intermittently existed on the shelf, the relative MS-III thickness and patterns

210 of erosion within the ASB catchment suggest maximum grounding line retreat of $\sim 150$

211 kilometers ${ }^{15}$ from its present location since the late Miocene. Thus, in contrast to the 
212 adjacent Wilkes Subglacial Basin ${ }^{14}$, the ASB did not contribute significantly to sea level

213 rise during Pliocene warmth ${ }^{15,16}$.

215 Sabrina Coast shelf records reveal the importance of atmospheric temperatures and

216 surface-derived meltwater to Antarctica's ice mass balance. Although deeper, more

217 continuous sampling of these sediments is required to assess the timing, magnitude, and

218 rates of EAIS evolution in the ASB, the ice-proximal Sabrina Coast shelf record confirms

219 model predictions of the region's long-term sensitivity to climate ${ }^{10,11,15,25,26}$. Critical for

220 future global sea level rise scenarios is the potential for ASB catchment glaciers to revert

221 from the extensive polar system of the last $\sim 7 \mathrm{Ma}$ to the surface meltwater-rich sub-polar

222 system of the Oligo-Miocene (Fig. 3a), when average global temperatures and

223 atmospheric $\mathrm{CO}_{2}$ concentrations were similar to those anticipated under current warming

224 projections (Figs. 3b-c) $)^{10,11,17}$. Presently, the Totten Glacier is thinning faster than any

225 other East Antarctic outlet glacier ${ }^{11,27,28}$ due to ocean thermal forcing ${ }^{28}$. Our findings

226 suggest that ice in the ASB catchment may respond dramatically to anthropogenic

227 climate forcing if regional atmospheric warming results in surface meltwater production.

\section{References}

1. Kennett J.P. Cenozoic evolution of Antarctic glaciation, the circum-Antarctic ocean, and their impact on global paleoceanography. J. Geophys. Res. 82, 38433860 (1977).

2. Coxall, H.K. et al. 2005. Rapid stepwise onset of Antarctic glaciation and deeper calcite compensation in the Pacific Ocean. Nature 433, 53-57 (2005).

3. Kominz, M.A., Browning, J.V., Miller, K.G., Sugarman, P.J., Mizintseva, S. \& Scotese, C.R. Late Cretaceous to Miocene sea-level estimates from the New Jersey and Delaware coastal plain coreholes: An error analysis. Basin Research 
20, 211-226 (2008).

4. Mudelsee, M., Bickert, T., Lear, C.H. \& Lohmann, G. Cenozoic climate changes: A review based on time series analysis of marine benthic $\delta^{18} \mathrm{O}$ records. Rev. Geophys. 52, 333-374 (2014).

5. Naish, T.R. et al. Orbitally induced oscillations in the East Antarctic ice sheet at the Oligocene/Miocene boundary. Nature 413, 719-723 (2001).

6. Naish, T.R. et al. Obliquity-paced Pliocene West Antarctic ice sheet oscillations. Nature 458, 322-328 (2009).

7. Cooper, A.K. et al. Cenozoic climate history from seismic reflection and drilling studies on the Antarctic Continental Margin. In: Florindo, F., Siegert, M. (Eds.), Antarctic Climate Evolution. Developments in Earth and Environmental Sciences. Elsevier, pp. 115-228 (2009).

8. Escutia, C., Brinkhuis, H., Klaus, A. \& Expedition 318 Scientists. Proc. Integrated Ocean Drilling Program 318 (Ocean Drilling Program Management International, Tokyo) (2011).

9. Fretwell, P. et al. Bedmap2: improved ice bed, surface and thickness datasets for Antarctica. Cryosphere 7, 375-393 (2013).

10. Golledge, N.R. et al. The multi-millennial Antarctic commitment to future sealevel rise. Nature 526, 421-425, (2015).

11. DeConto, R.M. \& Pollard, D. Contribution of Antarctica to past and future sealevel rise. Nature 531, 591-597 (2016).

12. Kehew, A.E., Piotrowski, J.A. \& Jørgensen, F. Tunnel valleys: Concepts and controversies - A review. Earth-Sci. Rev. 113, 33-58 (2012).

13. Herbert, T.D. et al. Late Miocene global cooling and the rise of modern ecosystems. Nat. Geosci. 9, 843-847 (2016).

14. Cook, C.P. et al. Dynamic behavior of the East Antarctic ice sheet during Pliocene warmth. Nat. Geosci. 6, 765-769 (2013).

15. Aitken, A.R.A. et al. Repeated large-scale retreat and advance of Totten Glacier indicated by inland bed erosion. Nature 533, 385-389 (2016).

16. Rovere, A. et al. The Mid-Pliocene sea-level conundrum: Glacial isostasy, eustacy, and dynamic topography. Earth Planet. Sci. Lett. 387, 27-33 (2014).

17. Masson-Delmotte V. et al. Information from paleoclimate archives. In Climate 
Change 2013: The Physical Science Basis. Contribution of Working Group I to the Fifth Assessment Report of the Intergovernmental Panel on Climate Change (T.F. Stocker et al. (eds.), pp. 383-464. Cambridge, UK: Cambridge University Press (2013).

18. Anagnostou, E. et al. Changing atmospheric $\mathrm{CO}_{2}$ concentration was the primary driver of early Cenozoic climate. Nature 533, 380-384 (2016).

19. DeConto, R.M. \& Pollard, D. Rapid Cenozoic glaciation of Antarctica induced by declining atmospheric $\mathrm{CO}_{2}$. Nature 421, 245-249 (2003).

20. Pälike H. et al. The heartbeat of the Oligocene climate system. Science 314, 18941898 (2006).

21. Liebrand, D. et al. Evolution of the early Antarctic ice ages. Proc. Natl. Acad. Sci. USA 114, 3867-3872 (2017).

22. Scher, H.D., Bohaty, S.M., Smith, B.W. \& Munn, G.H. Isotopic interrogation of a suspected late Eocene glaciation. Paleoceanography 29, 628-644 (2014).

23. Carter, A., Riley, T.R., Hillenbrand, C-D. \& Rittner, M. Widespread Antarctic glaciation during the late Eocene. Earth Planet. Sci. Lett. 458, 49-57 (2017).

24. Passchier, S., Ciarletta, D.J., Miriagos, T.E., Bijl, P.K. \& Bohaty, S.M. An Antarctic stratigraphic record of stepwise ice growth through the EoceneOligocene transition. GSA Bull. 129, 318-330 (2017).

25. Golledge, N.R., Levy, R.H., McKay, R.M., \& Naish, T.R. East Antarctic ice sheet most vulnerable to Weddell Sea warming. Geophys. Res. Lett. 44, 2343-2351 (2017).

26. Young, D.A. et al. A dynamic early East Antarctic Ice Sheet suggested by icecovered fjord landscapes. Nature 474, 72-75 (2011).

27. Li, X., Rignot, E., Mouginot, J., \& Scheuchl, B. Ice flow dynamics and mass loss of Totten Glacier, East Antarctica, from 1989 to 2015. Geophys. Res. Lett. 43, 6366-6373 (2016).

28. Rintoul, S.R. et al. Ocean heat drives rapid basal melt of the Totten Ice Shelf. Sci. $A d v$. 2, e1601610 (2016).

29. Wright, A.P. et al. Evidence of a hydrological connection between the ice divide and ice sheet margin in the Aurora Subglacial Basin, East Antarctica. J. Geophys. Res. 117, F01033, doi: 10.1029/2011JF002066 (2012).

30. Close, D.I., Stagg, H.M.J \& O’Brien, P.E. Seismic stratigraphy and sediment 
distribution on the Wilkes Land and Terre Adélie margins, East Antarctica. Mar. Geol. 239, 33-57 (2007).

Supplementary Information is available in the online version of this paper.

Acknowledgements We thank the NBP14-02 science party, ECO captain and crew, and ASC technical staff aboard the RV/IB N.B. Palmer. NBP14-02 was supported by the National Science Foundation (NSF PLR-1143836, -1143837, -1143843, -1430550, and -1048343) and a GSA graduate student research grant to C. Smith. We thank the Antarctic Marine Geology Research Facility staff at Florida State University for sampling assistance and E. Thomas, M. Katz, F. Sangiorni, P. Bijl, and S. Manchester for discussions. This is UTIG Contribution \#3137.

Author Contributions S.G. and A.S. contributed equally to this work, co-writing the manuscript with input from all authors. D.B., S.G., A.L., and A.S. conceived the study. B.F, R.F., S.G., A.L., A.S., C.S., and the shipboard scientific party collected geophysical data and samples on USAP cruise NBP14-02. All authors contributed to the analyses and interpretation of the results.

Author Information Reprints and permissions information is available at www.nature.com/reprints. The authors declare no competing financial interests. Readers are welcome to comment on the online version of the paper. Correspondence and requests for materials should be addressed to S.G. (sean@ig.utexas.edu). 


\section{Figure Captions}

358

359

360

361

362

363

364

365

373 and JPC-54, based on pollen (early-to-middle Eocene; beige shading). c, Seismic line 13

374 with cores relative to regional unconformity (light blue horizon). d, JPC-30 and -31

375 diatom biostratigraphy, with conservative (beige shading, red line) and preferred (brown

376 shading, blue line) ages.

378 Figure 3| Composite Sabrina Coast section with glacial surfaces and climate

379 indicators. a, Composite seismic line with pre- to pro-glacial Megasequence I (MS-I; 
380 black), glacial MS-II with erosion surfaces (initial: dark blue; subsequent: gray) overlain

381 by a non-glacial interval and regional unconformity (light blue), and polar glacial MS-III.

382 b, Cenozoic atmospheric $\mathrm{CO}_{2}$ reconstructions ${ }^{17,18}$ with 2 standard deviation error bars

383 (black). c, Composite high-latitude benthic formainifer $\delta^{18} \mathrm{O}$ record with blue uncertainty

384 band generated/calculated as per [4], reflecting global ice volume and deep ocean

385 temperatures ${ }^{4}$; d, New Jersey margin sea-level lowstands (black) with minimum

386 uncertainty (grey envelope) and best estimates (blue line) $)^{3}$.

388 METHODS

389 Seismic Data Acquisition, Processing, and Interpretation

390 The $750 \mathrm{~km}$ of 3-m resolution multichannel seismic data were acquired using dual

$39145 \mathrm{in}^{3}$ generator-injector (GI) guns and a 75-m long, 24-channel streamer in 2014 in

392 heavy ice conditions aboard the RV/IB N. B. Palmer. Data processing followed standard

393 steps of filtering, spherical divergence correction, normal moveout correction, and

394 muting, but no deconvolution was required due to the quality of the GI source. All

395 sediment thicknesses are presented in meters and based on a velocity of $2250 \mathrm{~m} / \mathrm{s}$;

396 seafloor depths are based on a velocity of $1500 \mathrm{~m} / \mathrm{s}$. Acoustic basement is the limit of our

397 reflectivity and interpreted as crystalline rock.

398 Seismic megasequences were identified based upon the presence or absence of

399 erosional surfaces and seismic facies of the mappable units within the sediment packages.

400 Seismic facies observed include: 1) stratified (laminated) or semi-stratified intervals

401 interpreted as open marine, 2) relatively continuous layers with variable reflectivity

402 interpreted as open marine conditions influenced by ice-rafting, and 3) chaotic, 
403 discontinuous or transparent intervals interpreted as glacial to periglacial conditions. MS-

404 I exhibits stratified, semi-stratified, and variably reflective (grey shading) intervals. MS-

405 II exhibits chaotic and discontinuous intervals related to erosive surfaces, stratified or

406 semi-stratified intervals, and prograding intervals. Rough, undulatory surfaces are

407 indicators of glacial advance on continental shelves ${ }^{31}$. MS-III consists of chaotic or

408 acoustically transparent intervals with thin intervals of stratified facies. The thickness of

409 stratified intervals between erosional surfaces may be a proxy for duration of open water

410 conditions and/or extent of ice retreat (and thus time/distance for readvance) ${ }^{32}$. Thus, MS-

411 II includes extensive and/or long-lasting glacial retreats whereas MS-III records localized

412 or relatively short-lived retreats.

413 All identified horizons are regionally mappable within the seismic survey area.

414 Glacial erosion surfaces are interpreted based on roughness, extent of down-cutting, and

415 association with overlying chaotic or discontinuous facies. Tunnel valley determinations

416 are based on comparisons with imaged tunnel valleys from the North Sea, Alaska, and

417 Svalbard ${ }^{32-38}$. Hydrologic modeling suggests tunnel valleys only form when meltwater

418 exceeds the capacity of flow through porous glacial substrate and any sheet flow at the

419 base of a glacier ${ }^{39}$. As tunnel valley size is expected to relate to discharge of subglacial

420 meltwater, Sabrina Coast glacial erosion surfaces 3-5 and 8-9 are interpreted as

421 meltwater-rich glaciations that likely required surface-derived meltwater. In the Ross Sea,

422 a widespread regional unconformity that separates prograding shelf strata from glacial

423 tills was interpreted to indicate widespread ice sheet expansion and the onset of ice

424 loading, as suggested for the Sabrina Coast angular unconformity underlying MS-III ${ }^{40}$.

425 Uninterpreted versions of the seismic profiles in Figs. 2a, $\mathrm{c}$ and 3a, including individual 
426 lines from the regionally representative cross-shelf composite line (Fig. 3a), are included

427 as Extended Data (Extended Data Fig. 1).

428

429 Marine sediment collection, description, and physical properties analyses

430 Marine sediments were collected in 440 to 550 meters of water 100-150 km

431 offshore, on the Sabrina Coast continental shelf (Extended Data Table 1). Geophysical

432 data guided the recovery of a suite of four $<2 \mathrm{~m}$ long jumbo piston cores (JPCs) that

433 targeted outcropping reflectors on the continental shelf (Figs. 1b, 2a, 2c, Extended Data

434 Figs. 2-4). Seismic data, lithology, benthic foraminifers, diatoms, and bulk sediment

435 geochemistry confirm that these sequences were deposited in open marine to subglacial

436 settings. Sediment cores were transported (unsplit and at $4^{\circ} \mathrm{C}$ ) to the Antarctic Marine

437 Geological Research Facility at Florida State University, where they were split,

438 photographed, visually described, x-rayed, and GEOTEK Multi-sensor Core Logger

439 (MSCL) data were collected following standard protocols. The radiographs were

440 interpreted in Adobe Photoshop with the contrast adjusted for each image. Organic

441 carbon, $\delta^{13} \mathrm{C}$, and $\delta^{15} \mathrm{~N}$ analyses of bulk sediments were conducted using a Carlo Erba

4422500 Elemental Analyzer coupled to a continuous flow ThermoFinigan Delta Plus XL

443 IRMS at USF CMS following standard methods. Lithologic, physical properties, and

444 geochemical data are shown in Extended Data Figures 2-4 and provided in

445 Supplementary Information (SI).

446 Core JPC-55 (1.69 m) contains two distinct lithologic units (Extended Data Fig.

$4472 \mathrm{~b})$. The upper unit (0-0.4 m; Unit 1) consists of Quaternary-recent diatom-rich sandy silt

448 with relatively high magnetic susceptibility (SI) overlying a more consolidated lower unit 
449 (0.4-1.69 m; Unit 2) of homogenous black micaceous silty fine sands with organic

450 detritus, rare pyrite nodules, macro- and microfossils, and a $\sim 10 \mathrm{~cm}$ diameter spherical

451 siderite concretion nucleated around a monocot stem (Extended Data Figs. 2b, d, e; SI).

452 Core JPC-54 $(1.21 \mathrm{~m})$, collected above the youngest clinoform, contains two

453 distinct lithologic units (Fig. 2a, Extended Data Fig. 3b). The lithology of the upper unit

$454(0-0.2 \mathrm{~m}$; Unit 1$)$ in JPC-54 is similar to that of JPC-55 and overlies a lower unit (0.2-

$4551.21 \mathrm{~m}$; Unit 2) composed of structureless gravel-rich sandy silts to silty coarse sands

456 with centimeter-scale angular lonestones throughout Units 1 and 2 (Extended Data Fig.

457 3b). A conservative approach to ice-rafted debris (IRD) interpretation was undertaken in

458 these sediments and only angular lonestones $\geq 1 \mathrm{~cm}$ were interpreted as IRD. Lighter

459 colored sediment with modern diatoms, visible on the right-hand side of JPC-54,

460 indicates flow-in below $\sim 80 \mathrm{~cm}$, likely due to a partial piston stroke; flowage of dark

461 sediment along the right side of the upper core is consistent with this interpretation and/or

462 on-deck or transport disturbance (Extended Data Fig. 3b). However, angular lonestones

463 are observed throughout and a majority are surrounded by the dark colored sediments.

464 Core JPC-30 (0.52 m plus cutter nose) contains diatom-bearing sandy muds, with

465 intervals of well-sorted sands $(0-0.25 \mathrm{~m})$. Sub-angular diatomite clasts are present in a

466 mud matrix between 0.25 and $0.52 \mathrm{~m}$. In the core cutter nose, we recovered stratified

467 diatomite and gravelly diatom-bearing sandstone and sandy diatomite above a sharp

468 contact with sandy diamictite below (Extended Data Fig. 4b).

469 Core JPC-31 $(0.47 \mathrm{~m})$ contains an upper unit of muddy diamicton $(0-0.29 \mathrm{~m})$.

470 Between 0.29 and $0.47 \mathrm{~m}$, angular diatomite clasts are present, which may have been

471 fractured during coring (Extended Data Fig. 4c). 


\section{Biostratigraphic methods}

$474 \quad$ Palynology: Nine samples from JPC-54 and eight samples from JPC-55

475 (Extended Data Figs. 2b, 3b, Extended Data Table 2) were processed at Global Geolab

476 Limited, Alberta, Canada using palynological techniques suited for Antarctic sediments.

477 Approximately five grams of dried sediment were weighed and spiked with a known

478 quantity of Lycopodium spores to allow computation of palynomorph concentrations.

479 Acid soluble minerals (carbonates and silicates) were removed via digestion in $\mathrm{HCl}$ and

480 HF acids. Residues were concentrated by filtration through a $10-\mu \mathrm{m}$ sieve and mounted

481 on microscope slides for analyses. Analysis was conducted under 100x oil immersion

482 objective with a Zeiss Axio microscope. For samples with sufficient palynomorph

483 abundance, a minimum of 300 palynomorphs were tabulated per sample. For samples

484 with low abundance, the entire residue was tabulated. A database of all palynomorphs

485 recovered was prepared and key species were photographically documented. The

486 taxonomic evaluation was completed based on the type specimen repository and library at

487 the Louisiana State University Center for Excellence in Palynology (CENEX).

488 Palynological results are presented in Extended Data Table 2.

489 Benthic Foraminifera: Benthic foraminifer counts and biostratigraphic data were

490 generated for 16 depths in JPC-55 and five depths in JPC-54 using standard protocols

491 (Extended Data Figs. 2b, 5, Extended Data Table 3). Sediment samples between 20 and

$49230 \mathrm{cc}$ were washed over a 63- $\mu \mathrm{m}$ sieve with deionized water. Sample residues were dried

493 at $50^{\circ} \mathrm{C}$ for 24 hours, transferred to labeled vials, dry sieved into 250 - and $150-\mu \mathrm{m}$

494 fractions, and examined using a Zeiss Stemi 2000-C stereomicroscope with a 1.6X lens 
495 and 10X eyepiece (Magnification: 10.4-80X). Genus and species identifications were

496 refined using Scanning Electron Microscopy (SEM) at the University of South Florida

497 College of Marine Science (Extended Data Fig. 5). All benthic foraminifer individuals

498 present in each JPC-55 sample are tabulated in Extended Data Table 3. In JPC-55,

499 preservation of aragonite and calcium carbonate tests, determined both visually and via

500 SEM, ranges from poor to excellent (Extended Data Fig. 5). Five species of well-

501 preserved aragonitic and calcareous benthic foraminifers were observed throughout JPC-

50255 Unit 2 (ED Table 3). No foraminifers were observed in JPC-54.

503 Diatoms: Diatom biostratigraphy was conducted on two sets of NBP14-02

504 samples: 1) JPC-30 cutter nose diatomites and 2) diatomite clasts from the bottom of

505 JPC-31 (Extended Data Figs. 4b, 4d, 6). Quantitative slides were prepared at Colgate

506 University for diatom assemblage studies and biostratigraphic evaluation using a settling

507 technique that results in a random and even distribution of frustules ${ }^{41}$; sub-samples were

508 sieved at 10- and $63-\mu \mathrm{m}$ to concentrate unbroken frustules for examination. Photographic

509 documentation at 1000x magnification using oil immersion on Olympus BX50 and BX60

510 microscopes was completed at Colgate University (Extended Data Fig. 6). The beige

511 shading in Fig. $2 d$ represents the conservative zonal assignment and age range, whereas

512 the brown shading represents the refined age interpretation. Age constraints for key

513 diatom bioevents are derived from the statistical compilation and analysis of average age

514 ranges for Southern Ocean taxa $a^{42 .}$

515

516 Chronology 
518 zonation of cores NBP14-02 JPC-54 and JPC-55 is based on the presence of a few key

519 species and limited data available from Antarctica and surrounding regions (e.g. Australia

520 and New Zealand). Gambierina edwardsii and Gambierina rudata are known as

521 Cretaceous to Paleocene species. A recent study published a robust LAD for these species

522 at the Paleocene/Eocene boundary on the East Tasman Rise (ODP Site 1172) ${ }^{43}$. However,

523 in southeastern Australia, the two Gambierina species observed in the Sabrina Coast

524 sequence range into the earliest early Eocene ${ }^{44}$. Extended ranges for the Gambierina sp.

525 (dashed lines; Fig. 2b) are based on the palynological analysis of ODP Site 1166 in Prydz

526 Bay $^{45,46}$, where abundant well-preserved Gambierina specimens were observed and not

527 considered reworked. Consequently, those authors extended the Gambierina sp. range

528 into the early-to-middle Eocene in East Antarctica ${ }^{45,46}$.

529 Microalatidites paleogenicus has a Paleogene to Neogene range ${ }^{46}$. Although we

530 are adopting their range herein, there is some controversy with this range. The first

531 occurrence of Microalatidites paleogenicus is listed as Senonian in Australia and New

532 Zealand ${ }^{47}$, but there is no robust evidence supporting an extended range in Antarctica. In

533 Fossilworks (PaleoDB taxon number: 321781), Microalatidites paleogenicus is listed as

534 having a range from 55.8 to $11.608 \mathrm{Ma}$.

535 Nothofagidites lachlaniae ranges from Paleogene to modern while Nothofagidites

536 flemingii-rocaensis ranges from Paleogene to Neogene ${ }^{46}$. The range for $N$. lachlaniae in

537 New Zealand is listed as Late Cretaceous to present and is similar to other forms ${ }^{48}$. In the

538 Paleocene and Eocene, there is climatically-induced variability observed in the

539 Nothofagidites ranges. For example, broad regional vegetation changes (e.g. the 
540 abundance of Nothofagidites lachlaniae in western Southland (Ohai, Waiau and Balleny

541 basins) and its scarcity in other Eocene sections (Waikato, the Taranaki basin, and the

542 west coast of New Zealand's South Island) may be related to paleoenvironmental

543 factors $^{49}$. The type material is Pliocen ${ }^{50}$, but the distinction of this species from other

544 Fuscospora pollen (including $N$. brachyspinulosa and N. waipawaensis) is problematic.

545 If $N$. waipawaensis and $N$. senectus are excluded, then the New Zealand FAD of other

546 Fuscospora pollen would be late Paleocene.

547 In Southern Australia, the FAD of N. flemingii is in the upper part of the

548 Lygistepollenites balmei Zone (late Paleocene) $)^{51,52}$. However, in a detailed study of

549 Paleocene-Eocene transition strata in western Victoria, $N$. flemingii is not reported ${ }^{53}$. In

550 New Zealand, the $N$. flemingii FAD is reported as middle Eocene ${ }^{54,55}$. However, in well-

551 dated early Eocene New Zealand localities, occasional small N. flemingii-like specimens

552 are observed; their identification is under debate. Due to the relative geographic

553 proximity of East Antarctica and Southern Australia in the Paleogene, we follow [52, 53]

554 and place the FADs of both species in the late Paleocene.

555 Proteacidites tenuiexinus has a range from 66.043 to $15.97 \mathrm{Ma}$ (PaleoDB taxon

556 number: 277519 at fossilworks.org). We adopt the published late Paleocene Proteacidites

557 tenuiexinus FAD in Southeastern Australia ${ }^{51}$, but acknowledge that the FAD could be as

558 early as early Paleocene.

559 Two pollen species present in core JPC-54 were not observed in core JPC-55,

560 Nothofagidites cranwelliae and Nothofagidites emarcidus. Most verified references for

561 Nothofagidites cranwelliae and Nothofagidites emarcidus (e.g. those with specimens

562 properly identified; the Nothofagidites group is diverse, complex, and easily 
563 misidentified) place the FAD of both of these species in the early Eocene, at the

564 earliest $^{56,57}$. The latter species was also found in the Eocene of Western Australia ${ }^{58}$.

565 Diatom preservation and biostratigraphy: The diatom assemblages present in

566 cores JPC-30 and JPC-31 are indistinguishable, although preservation is better and

567 abundance higher in the JPC-31 diatomites compared to the sandy diatom muds

568 recovered in JPC-30. Overall, preservation is moderate to good in JPC-31 and poor to

569 moderate in JPC-30 (Extended Data Fig. 6). Diatoms in both cores suffer from a high

570 degree of fragmentation. Large centric taxa, such as Actinocyclus spp. and Thalassiosira

571 spp., are generally broken, whereas the smaller centric and pennate specimens are well

572 preserved (Extended Data Fig. 6). Denticulopsis specimens are generally well preserved,

573 although though the longer specimens of $D$. delicata are typically broken. Rouxia spp.

574 occur mostly in fragments making identification more problematic. Similarly, specimens

575 of Fragilariopsis spp. are dominantly present as broken specimens, with the exception of

576 a few $F$. praecurta specimens (Extended Data Fig. 6).

577 Many of the diatom species present in both JPC-30 and JPC-31 have long age

578 ranges and do not provide good biostratigraphic age constraints (e.g., Coscinodiscus

579 marginatus, Trinacria excavata). However, the presence of several common taxa

580 provides robust support for a late Miocene-earliest Pliocene age. These taxa include:

581 Actinocylus ingens var. ovalis, Denticulopsis delicata, Fragilariopsis praecurta,

582 Thalassiosira oliverana var. sparsa, Thalassiosira torokina (large form), and

583 silicoflagellates in the Distephanus speculum speculum 'pseudofibula plexus' group.

584 There is very little evidence of reworking of older material, with only one specimen of

585 Pyxilla sp. and a fragment of Hemiaulus sp. observed; all species within both of these 
genera are typical of the Eocene and Oligocene.

588 zonation scheme, we favor a late Paleocene to earliest early Eocene age for the

589 exceptionally diverse JPC-55 in situ fossil pollen assemblage; this assemblage is easily

590 distinguishable from reworked Cretaceous microfossils present in the sediments (Fig. 2b).

591 The presence of middle bathyal benthic foraminifer species Gyroidinoides globosus and

592 Palmula sp., both of which went extinct at the Paleocene-Eocene boundary ${ }^{59}$, enables us

593 to further refine the pollen-based age designation to late Paleocene (Extended Data Fig.

594 5). Although its first occurrence may be diachronous, the presence of aragonitic Cenozoic

595 benthic foraminifer species Hoeglundina elegans ${ }^{59-63}$ indicates that these sediments are

596 Cenozoic in age, confirming the interpretation that co-occurring Cretaceous microfossils

597 are reworked. H. elegans and other aragonitic benthic foraminifers are most common in

598 upper to middle bathyal assemblages along the southern Australian margin and the

599 Australo-Antarctic Gulf during the Paleocene and Eocene ${ }^{60,63}$. Thus, we conservatively

600 designate an age of late Paleocene to sediments in the lower unit (Unit 2) of JPC-55 (Fig.

601 2b, Extended Data Fig. 2b).

602 Age determination for JPC-54 sediments: Pollen bistratigraphy constrains the

603 depositional age of JPC-54 Unit 2 sediments to the early-to-middle Eocene (Fig. 2b,

604 Extended Data Fig. 3b). No foraminifers are observed in the lower lithologic unit of JPC-

605 54. Thus, based on the pollen assemblage alone, we favor an early-to-middle Eocene age

606 for sediments in the lower unit (Unit 2) of JPC-54.

607 Age determination for JPC-30 and JPC-31 sediments: Based on Southern Ocean

608 diatom ages ${ }^{42}$, the FAD of T. oliverana var. sparsa (8.61 Ma) and the LAD of T. ingens 
var. ovalis $(4.78 \mathrm{Ma})$ provide a conservative age estimate for the diatom assemblages

610 present in JPC-30 and JPC-31 (8.61-4.78 Ma; Fig. 2d). A more restricted age

611 interpretation is possible if the presence of Shionodiscus tetraoestrupii (FAD 6.91 Ma)

612 and the absence of the typical early Pliocene taxon Thalassiosira inura (FAD 5.59 Ma)

613 are considered, indicating an age between 6.91 and 5.59 Ma (Fig 2d). This more

614 restricted age should be considered tentative, since precise calibrations for many

615 Southern Ocean diatom bioevents in the Chron C3-C3A (4.2-7.1 Ma) interval are

616 compromised by multiple short hiatuses at many drill sites and poor magnetostratigraphy.

617 Further age refinement for the JPC-30 and JPC-31 samples is likely possible as diatom

618 biostratigraphic data are published for expanded Late Neogene sections recovered on the

619 Wilkes Land margin ${ }^{64}$. However, the more conservative age estimate (8.61-4.78 Ma; Fig.

$6202 \mathrm{~d}$ ) is well supported by the presence of several taxa with well-calibrated ages in the

621 Southern Ocean, including Rouxia naviculoides (FAD 9.84 Ma), Thalassiosira oliverana

622 (FAD 9.73 Ma), and Thalassiosira torokina (FAD 9.36 Ma). The absence of

623 Denticulopsis dimorpha (LAD 9.75 Ma, Denticulopsis ovata (LAD 8.13), Thalassiosira

624 complicata (FAD 5.12 Ma), Fragilariopsis barronii (FAD 4.38 Ma), and Fragilariopsis

625 interfrigidaria (FAD 4.13 Ma) support this age assessment.

626

627 Data availability. The seismic data from the study are available in the Academic Seismic

628 Datacenter at the University of Texas Institute for Geophysics (http://www-

629 udc.ig.utexas.edu/sdc/cruise.php?cruiseIn=nbp1402). Sediment cores are archived in the

630 NSF-funded Antarctic Core Repository at Oregon State University. The authors declare

631 that all other data that support the findings of this study are available within the paper and 
632 its supplementary information files; these data may also be downloaded from the US

633 Antarctic Program Data Center (USAP-DC; www.usap-dc.org).

635

636

637

638

639

640

641

642

643

644

645

646

647

648

649

650

651

652

653

654

655

656

657

658

659

660

661

662

663

664

665

666

667

668

669

670

671

672

673

674

\section{Methods References}

31. Anderson, J. \& Bartek, L.R. Cenozoic glacial history of the Ross Sea revealed by intermediate resolution seismic reflection data combined with drill site information. pp. 213-263 in The Antarctic Paleoenvironment: A Perspective on Global Change. J.P. Kennett and D.A. Warnke, eds., Antarctic Research Series, vol. 56, American Geophysical Union (1992).

32. Ó'Cofaigh, C. Tunnel valley genesis. Prog. Phys. Geog. 20, 1-19 (1996).

33. Huuse, M. \& Lykke-Andersen, H. Over-deepened Quaternary valleys in the eastern Danish North Sea: morphology and origin. Quat. Sci. Rev. 19,1233-1253 (2000).

34. Denton, G.H. \& Sugden, D.E. Meltwater features that suggest Miocene ice-sheet overriding of the Transantarctic Mountains in Victoria Land, Antarctica. Geogr. Ann. A 87, 67-85 (2005).

35. Lonergan, L., Maidment, S. \& Collier, J. Pleistocene subglacial tunnel valleys in the central North Sea basin: 3-D morphology and evolution. J. Quat. Sci. 21, 891903 (2006).

36. Elmore, C.R., Gulick, S.P.S., Willems, B., \& Powell, R., Seismic stratigraphic evidence for glacial expanse during glacial maxima in the Yakutat Bay Region, Gulf of Alaska. Geochem. Geophys. Geosys. 14, p. 1294-1311 (2013).

37. Van der Vegt, P., Janszen, A., \& Moscariello, A. Tunnel valleys: current knowledge and future perspectives. Geol. Soc. London Spec. Publ. 368, 75-97 (2012).

38. Bjarnadóttir, L.R., Winsborrow, M.C.M., \& Andreassen, K. Large subglacial meltwater features in the central Barents Sea. Geology 45,159-162 (2017).

39. Piotrowski, J.A. Subglacial hydrology in north-western Germany during the last glaciation: Groundwater flow, tunnel valleys and hydrologic cycles. Quat. Sci. Rev 16, 169-186 (1997).

40. Bart, P.J. Were West Antarctic Ice Sheet grounding events in the Ross Sea a consequence of East Antarctic Ice Sheet expansion during the middle Miocene? Earth Planet. Sci. Lett. 216, 93-107 (2003). 
41. Scherer, R.P. A new method for the determination of absolute abundance of diatom and other silt-sized sedimentary particles. J. Paleolimnology 12, 171-179 (1994).

42. Crampton, J.S. et al. Southern Ocean phytoplankton turnover in response to stepwise Antarctic cooling over the past 15 million years. Proc. Natl. Acad. Sci. USA 113, 6868-6873 (2016).

43. Contreras, L. et al. Southern high-latitude terrestrial climate change during the Paleocene-Eocene derived from a marine pollen record (ODP Site 1172, East Tasman Plateau). Clim. Past Discuss. 10, 291-340 (2014).

44. Partridge, A.D. Late Cretaceous-Cenozoic palynology zonations Gippsland Basin, Australian Mesozoic and Cenozoic palynology zonations-update to the 20004 Geologic Time Scale, Geoscience Australia, Record 2006/23 (2006).

45. MacPhail, M.K.\& Truswell, E.M. Palynology of Site 1166, Prydz Bay, East Antarctica. In Cooper, A.K., O'Brien, P.E. \& Richter, C. (Eds.), Proc. ODP, Sci. Results 188, 1-43 (2004).

46. Truswell, E.M. \& MacPhail, M.K. Fossil forests on the edge of extinction: What does the fossil spore and pollen evidence from East Antarctica say? Austral. Syst. Bot. 22, 57-106 (2009).

47. Raine, J.I., Mildenhall, D.C. \& Kennedy, E.M. New Zealand fossil spores and pollen: an illustrated catalogue. 4th edition. GNS Science Miscellaneous Series, 4, http://data.gns.cri.nz/sporepollen/index.htm (2011).

48. Hill, R.S. (Ed.). History of the Australian vegetation: Cretaceous to Recent. Cambridge University Press (Cambridge). p. 233 (1994).

49. Truswell, E. M. Recycled Cretaceous and Tertiary pollen and spores in Antarctic marine sediments: a catalogue. Palaeontographica Abt. B 186, 121-174 (1983).

50. Pocknall, D.T. Late Eocene to early Miocene vegetation and climate history of New Zealand, J. R. Soc. N.Z. 19, 1-18 (1989).

51. Dettmann, M.E., Pocknall, D.T., Romero, E.J. \& Zamalao, M. del C. Nothofagidites Erdtman ex Potonie, 1960; a catalogue of species with notes on the paleogeographic distribution of Nothofagus BI. (Southern Beech). N.Z. Geol. Sur. Paleo. Bull. 60, 1-79 (1990).

52. Stover, L.E. \& Partridge, A.D. Tertiary and Late Cretaceous spores and pollen from the Gippsland Basin, southeastern Australia. Proc. Roy. Soc. Victoria 85, 237-286 (1973). 
53. Stover, L.E. \& Evans, P.R. Upper Cretaceous-Eocene spore-pollen zonation, offshore Gippsland Basin, Australia. Geol. Soc. Australia Spec. Pub. 4, 55-72 (1973).

54. Harris, W.K. Basal Tertiary microfloras from the Princetown area, Victoria, Australia. Palaeontographica Abt. B 115, 75-106 (1965).

55. Couper, R.A. New Zealand Mesozoic and Cainozoic plant microfossils. N.Z. Geol. Sur. Paleo. Bull. 32, 87 pages (1960).

56. Raine, J.I. Outline of a palynological zonation of Cretaceous to Paleogene terrestrial sediments in west coast region, South Island, New Zealand. N.Z. Geol. Survey Rept. 109, 1-82 (1984).

57. Greenwood, D.R., Moss, P.T., Rowett, A.I., Vadala, A.J. \& Keefe, R.L. Plant communities and climate change in southeastern Australia during the early Paleogene. Geol. Soc. Spec. Pap. 369, 365-380 (2003).

58. Stover, L.E. \& Partridge, A.D. Eocene spore-pollen from the Werillup Formation, Western Australia. Palynology 6, 69-96 (1982).

59. Thomas, E. Late Cretaceous through Neogene deep-sea benthic foraminifers (Maud Rise, Weddell Sea, Antarctica). Proc. ODP, Sci. Res. 113, 571-594 (1990).

60. McGowran, B. Two Paleocene foraminiferal faunas from the Wangerrip Group, Pebble Point Coastal section, Western Victoria. Proc. Roy. Victoria 79, 9-74 (1965).

61. Brotzen, F. The Swedish Paleocene and its Foraminiferal Fauna. Arsbok Sveriges Geologiska Undersokning, 42, 1-140 (1948).

62. Holbourn, A., Henderson, A. \& MacLeod, N. Atlas of Benthic Foraminifera. Wiley-Blackwell, London, England. 634 pp (2013).

63. Li, Q., James, N.P. \& McGowran, B. Middle and late Eocene Great Australian Bight lithobiostratigraphy and stepwise evolution of the southern Australian continental margin. Aus. J. Earth Sci. 50, 113-128 (2003).

64. Tauxe, L. et al. Chronostratigraphic framework for the IODP Expedition 318 cores from the Wilkesland Margin: Constraints for paleoceanographic reconstruction. Paleoceanography 27, PA2214, doi:10.1029/2012PA002308 (2012). 
Extended Data Figure 1| Uninterpreted NBP14-02 seismic profiles with line crossings and coring sites indicated. a, Line 13 with piston core sites JPC-30 and JPC31 and formation penetration depths indicated by red lines. b, Line 17 with core sites JPC-55 and JPC-54 and formation penetration depths indicated by red lines. c, Line 07 showing intersection with Line 10. d, Line 10 showing intersections with Line 07 and Line 21. e, Line 21 showing intersection with Line 10.

Extended Data Figure 2| Site location and sedimentological, geochemical, and paleontological data from piston core NBP14-02 JPC-55 plotted versus depth. a, CHIRP record of JPC-55 site; location and penetration indicated (red line); site coordinates and multibeam depth (MB) included. b, Gastropod steinkern $(70-72 \mathrm{~cm})$. c, Siderite concretion with monocot stem nucleus $(118-125 \mathrm{~cm})$. d, Close-up of monocot stem. e, JPC-55 lithologic unit, photograph, x-ray radiograph, graphic lithology, coring disturbance, sedimentary structures, lithologic accessories, sample locations, age, benthic foraminifers/30 cc sediment, magnetic susceptibility, GRA bulk density (grams/cc sediment), bulk sediment $\delta^{13} \mathrm{C}_{\text {org }}$ (per mil; VPDB\%o), and Carbon/Nitrogen (C/N) plotted versus depth in in centimeters below sea floor (cmbsf; SI).

\section{Extended Data Figure 3| Site location and sedimentological and geochemical data} from piston core NBP14-02 JPC-54 plotted versus depth. a, JPC-54 lithologic unit, photograph, x-ray radiograph, graphic lithology, coring disturbance, sedimentary structures, lithologic accessories, sample locations, age, magnetic susceptibility (SI), GRA bulk density (grams/cc sediment), and bulk sediment $\delta^{13} \mathrm{C}_{\text {org }}$ (per mil; VPDB\%o) plotted versus depth in centimeters below sea floor (cmbsf). b, CHIRP record of JPC-54 site; location and penetration indicated (red line); site coordinates and multibeam depth (MB) included.

Extended Data Figure 4| Site location and sedimentological data from piston cores NBP14-02 JPC-30 and JPC-31 plotted versus depth. a, CHIRP record of JPC-30 site; location and penetration indicated (red line); site coordinates and multibeam depth (MB) included. b, JPC-30 lithologic unit, photograph, x-ray radiograph, graphic lithology, coring disturbance, sedimentary structures, lithologic accessories, sample locations, age, magnetic susceptibility (SI), and GRA bulk density (grams/cc sediment) plotted versus depth in centimeters below sea floor (cmbsf). c, CHIRP record of JPC-31 site; location, and penetration indicated (red line). d, JPC-31 lithology, age, and physical properties as above.

Extended Data Figure 5| Benthic foraminifers from piston core NBP14-02 JPC-55. a, Hoeglundina elegans (76-78 cmbsf). b, SEM of Hoeglundina elegans (76-78 cmbsf). c, Ceratobulimina sp. (70-72 cmbsf). d, Ceratobulimina sp. (70-72 cmbsf). e, SEM of Ceratobulimina sp. (70-72 cmbsf). f, SEM of Gyroidinoides globosus (110-113 cmbsf). g, SEM of Gyroidinoides globosus (110-113 cmbsf). h, Gyroidinoides globosus with pyrite (136-138 cmbsf). i, Gyroidinoides globosus with zoom in of umbilicus; pyrite on lower right side of test (136-138 cmbsf). j, Palmula sp. (136-138 cmbsf; test $>450 \mu \mathrm{m})$. 
812 Extended Data Figure 6| Siliceous microfossils from piston core NBP14-02 JPC-31 813 diatomite sample. a, Thalassiosira torokina. b, Thalassiosira oliverana var. sparsa. c, 814 Actinocyclus ingens var. ovalis. d, Coscinodiscus marginatus. e, Azpeitia sp. 1. f, 815 Actinocyclus sp. g, Actinocyclus sp. h, Shionodiscus tetraoestrupii. i, Shionodiscus 816 tetraoestrupii. j, Shionodiscus oestrupii. k, Denticulopsis delicate. 1, Denticulopsis 817 simonsenii/D. vulgaris. m, Denticulopsis simonsenii/D. vulgaris. $\mathbf{n}$, Denticulopsis 818 delicate. o, Denticulopsis simonsenii/D. vulgaris. p, Rouxia naviculoides. q, 819 Fragilariopsis praecurta. r, Fragilariopsis sp. 1. s, Trinacria excavate. t, Rhizosolenia 820 hebetate. u, Eucampia antarctica var. recta. v, Distephanus speculum speculum $\mathrm{f}$. 821 varians. Sample from 43-45 cmbsf.

823 Extended Data Table 1| NBP14-02 piston core locations, water depths, and 824 recovered core lengths.

Extended Data Table 2| Piston core NBP14-02 JPC-55 and JPC-54 raw terrestrial 

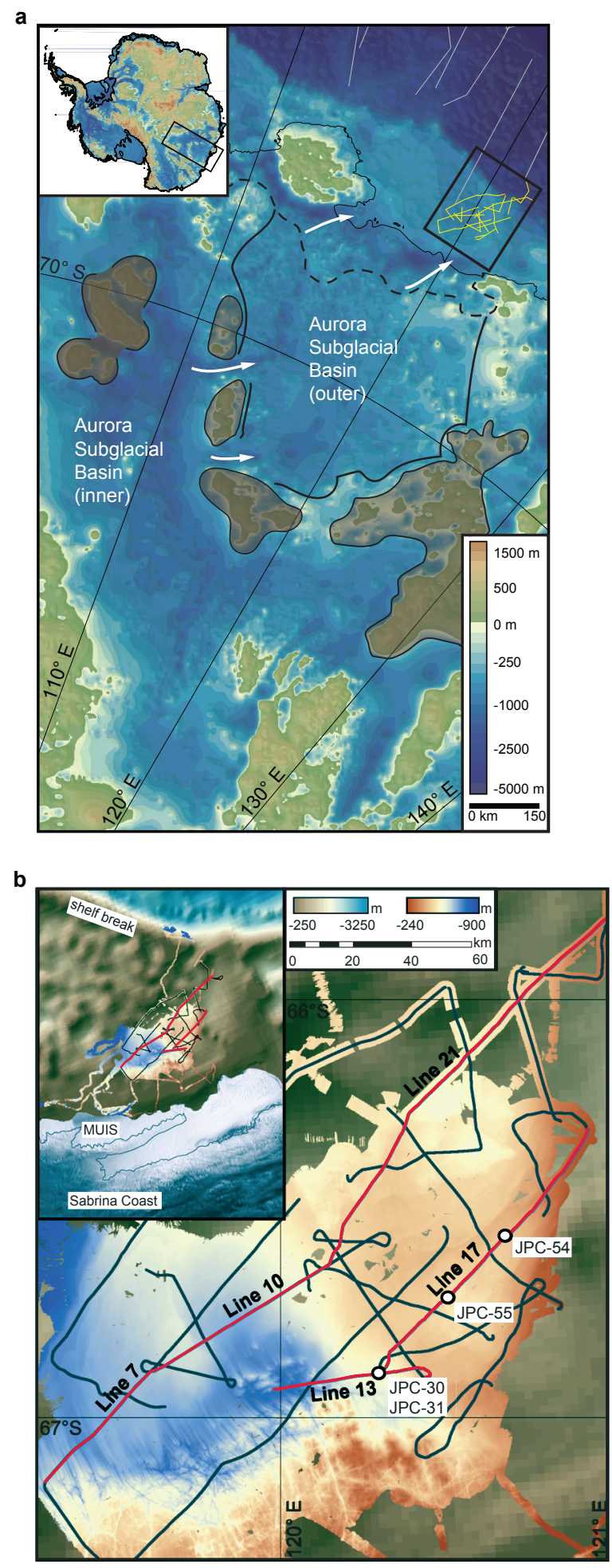

Gulick et al_Fig. 1 
a

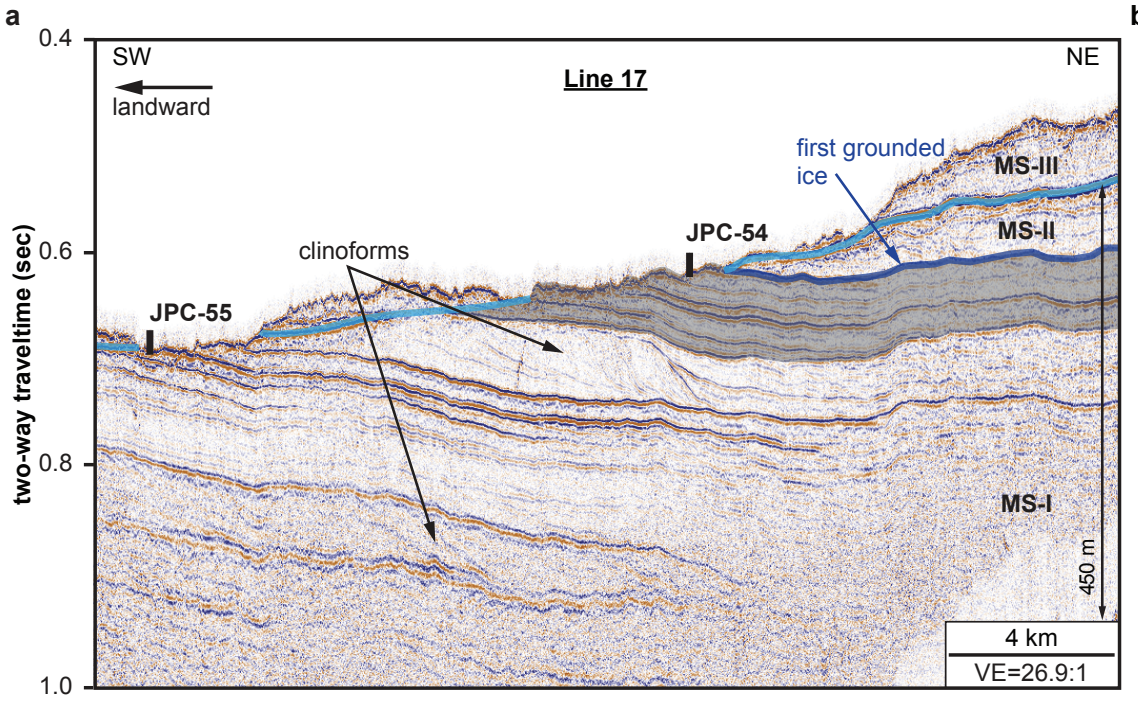

C

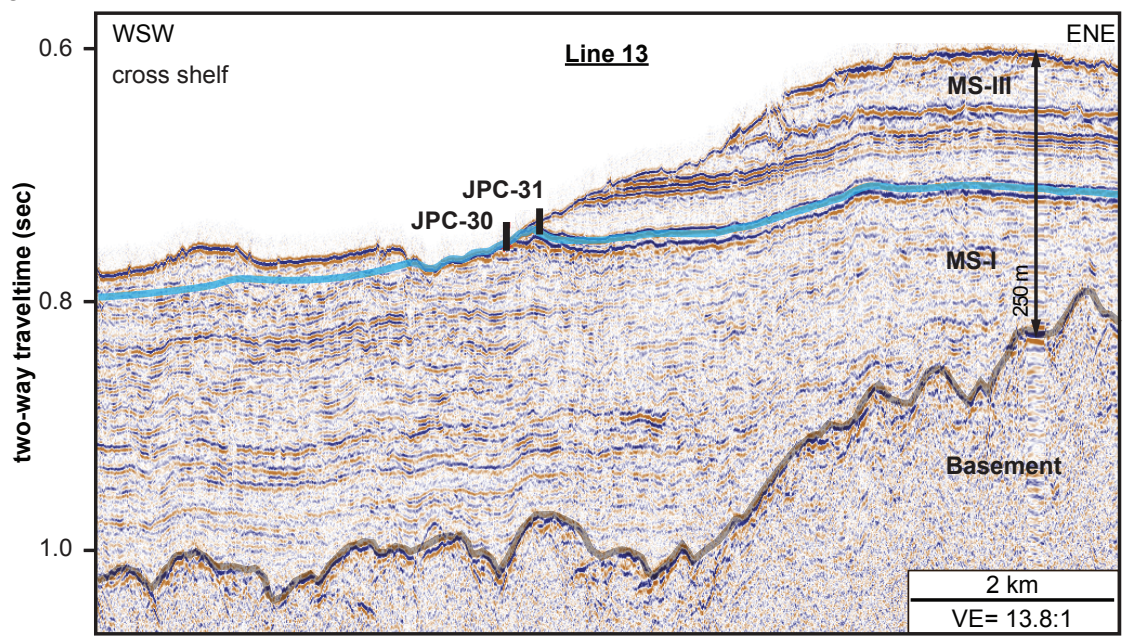

b

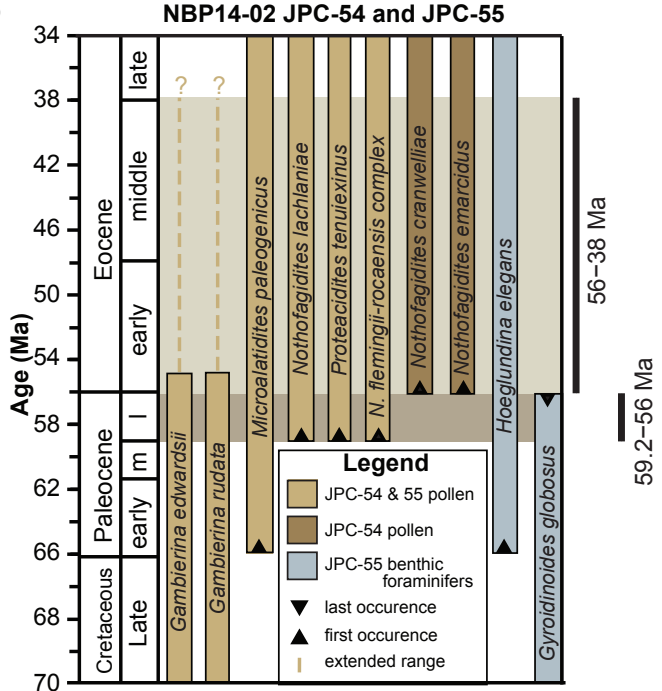

d

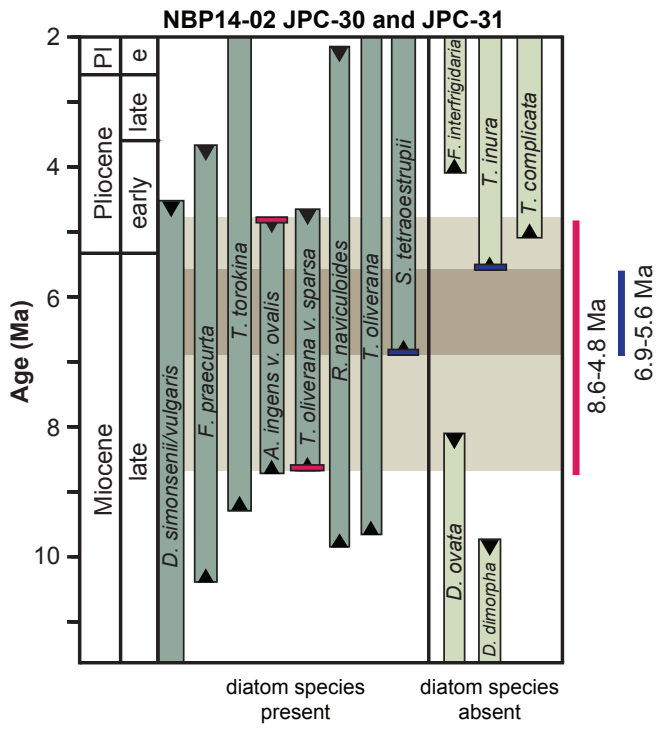



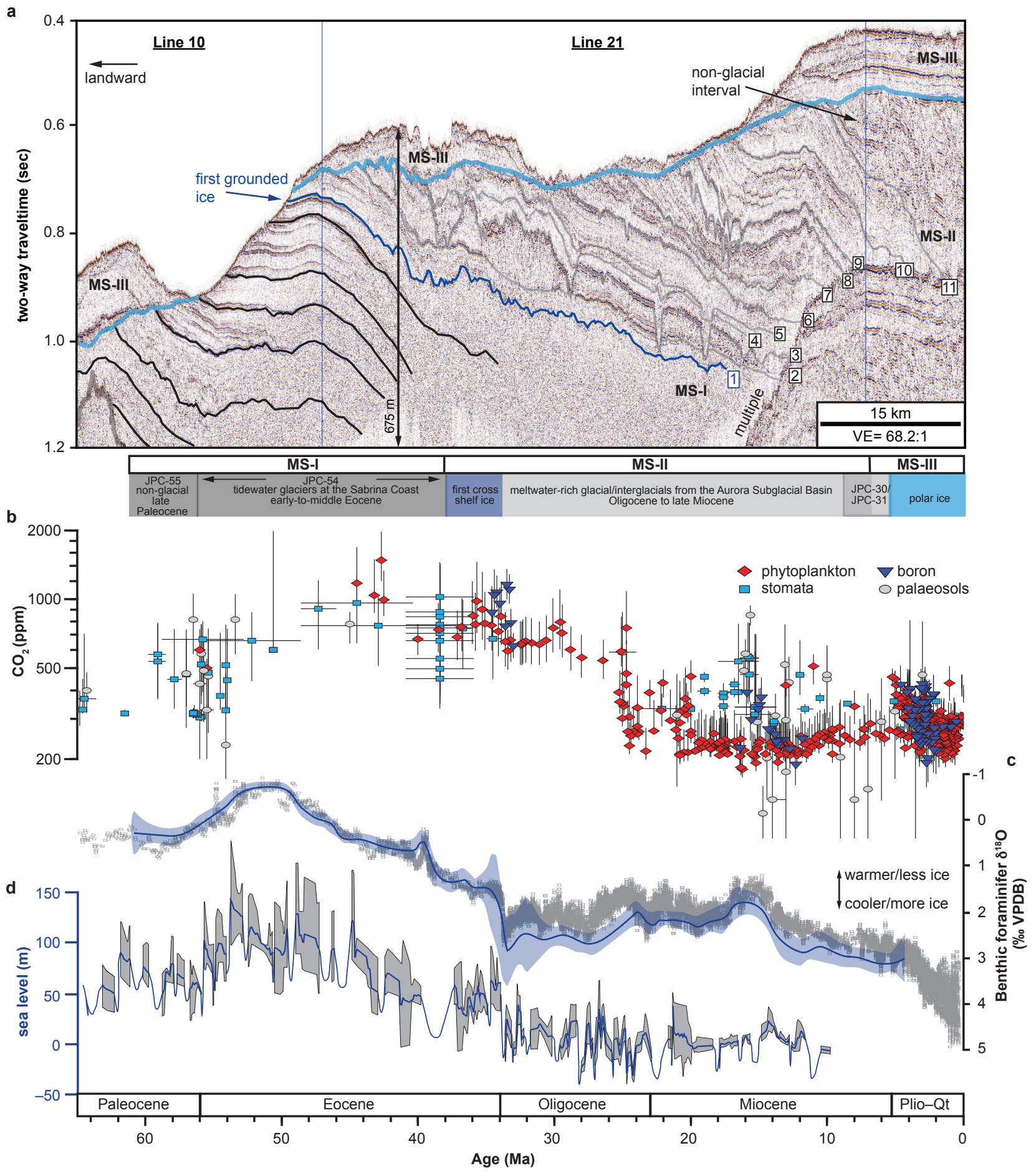

Gulick et al_Fig, 3 